\title{
Yenidoğanda Kalsiyum Tedavisi Sonrası Deri Kalsinozisi: iki Olgu Sunumu
}

\section{Calcinosis Cutis Following Intravenous Administration of Calcium Gluconate in Newborn: Two Case Reports}

\author{
Zelal Kahramaner, Aydın Erdemir, Sümeyye Ercan, Mehmet Tekin, Velat Çelik \\ Adıyaman Üniversitesi Tıp Fakültesi, Kadın Doğum ve Çocuk Hastanesi, Yenidoğan Kliniği, Adıyaman, Türkiye
}

\begin{abstract}
ÖZET
Extravazasyon hasarları, intravenöz tedavinin istenmeyen ciddi komplikasyonlarından biridir. Hastanın yaşı, bilinç durumuve venöz dolaşımı extravazasyon riskini etkiler. Yenidoğanlar küçük damar ve matur olmayan derileri nedeni ile yüksek extravazasyon riskine sahiptirler. Yenidoğan yoğun bakım ünitelerinde, extravazasyon hasarlarına en sık intravenöz kalsiyum tedavisi sebep olmaktadır. lyatrojenik kalsiyum extravazasyonuna bağlı olarak lokalize doku kalsifikasyonu, nekroz, selülit, osteomyelit ve Kompartman sendromu gelişebilmektedir. Burada cilt üzerinde belirgin lezyon olmayan iyatrojenik kalsiyum extravazasyonuna bağlı deri kalsinozisi gelişen iki yenidoğan olgusu kalsiyum içeren solüsyonların, hafif, subklinik extravazasyonunun deri kalsinozisine yol açabileceğini ve her ne kadar komplikasyonun görünümü aileleri endişelendirse de uzun dönem ciddi bir sekel oluşturmadan ve agresif tedaviye gerek duyulmadan spontan olarak iyileşebildiğini vurgulamak amacı ile sunuldu. The Journal of Pediatric Research 2014;1(1):46-8

Anahtar Kelimeler: Deri kalsinozisi, ekstravazasyon hasarı, kalsiyum glukonat, yenidoğan
\end{abstract}

\begin{abstract}
Extravasation injuries are undesired serious complications of intravenous therapy. The age, state of consciousness, and venous circulation of the patient affect the risk of extravasation injury. Newborns are at high risk of these injuries because of immature skin and vessel. Intravenous calcium treatment is the most common cause of extravasation injury in neonatal intensive care units. Localized tissue calcification, necrosis, cellulitis, osteomyelitis and Compartment syndrome may occur due to iatrogenic extravasation of calcium. Here, we reported two cases that developed calcinosis cutis following intravenous administration of calcium glucanate to draw attention to the fact that the minor, initially subclinical, extravasation of calcium-containing solutions can produce lesions of calcinosis cutis and although the families are worried about the appearance of complication, the injury heals spontaneously without the need of agressive treatment with no serious long-term sequelae.The Journal of Pediatric Research 2014;1(1):46-8
\end{abstract}

Key Words: Calcium glucanate, cutis calcinosis, extravasation injury, newborn

\section{Giriş}

Ekstravazasyon hasarları, intravenöz tedavinin istenmeyen ciddi komplikasyonlarından biridir. Hastanın yaşı, bilinç durumu ve venöz dolaşımı ekstravazasyon riskini etkiler. Yenidoğanlar küçük damar ve matur olmayan derileri nedeni ile yüksek ekstravazasyon riskine sahiptirler. Ekstravazasyon hasarlarına en sık sebep olan intravenöz kalsiyum tedavisi yenidoğan yoğun bakım ünitelerinde sık yapılan bir uygulamadır $(1,2)$. Iyatrojenik kalsiyum ekstravazasyonuna bağlı olarak lokalize doku kalsifikasyonu, nekroz, selülit, osteomyelit ve Kompartman sendromu gelişebilmektedir (3).

Burada intravenöz verilen kalsiyum glukonat tedavisinin ciltte hasar yapmadan deri altı dokuya ekstravazasyonu sonrası gelişen deri kalsinozisin tedavisiz izlem ile gerilediğini vurgulamak amacı ile iki yenidoğan olgusu sunuldu.

Yazıșma Adresi/ Address for Correspondence 


\section{Olgu Sunumu}

\section{Olgu 1}

Miadında normal spontan vajinal yol ile mekonyumlu boyalı olarak 3300 gram doğan kız bebek, postnatal birinci gününde neonatal sepsis ön tanısı ile yenidoğan servisine yatırılıp 10 günlük tedavi ile taburculuktan iki hafta sonra sağ el bileği üzerinde şişlik şikayeti ile başvurdu. Şişlik dışında şikayeti olmayan olgunun fizik muayenesinde aktif, canlı görünümde, sağ el bileğinde üzerini örten deri sağlam görünümde olup, 2x3 cm boyutunda hareketli kitle palpasyonu dışında patoloji saptanmadı. El bileğinin çekilen direk grafisinde cilt altında kemik dokusuna benzer kalsifikasyon görüldü (Resim 1). Hemogram, kalsiyum, fosfor, alkalen fosfataz ve parathormon değerlerinide içeren biyokimya parametreleri normal aralıklarda, enfeksiyon parametreleri negatif saptandı. Hastanın yatış epikrizinde beslenemediği günlerde kitle lokalizasyonuna uyan bölgede periferik yerleşimli intravenöz kateterle kalsiyum glukonat içeren intravenöz sıvı tedavisi aldığı öğrenildi. Intravenöz kalsiyum glukonat ekstravazasyonuna bağlı subkutan kalsinozis düşünülen olgu izleme alındı. Iki ay sonra şişliğin gerilediği ve direk grafide kalsifikasyonun tamamen rezorbe olduğu görüldü.

\section{Olgu 2}

Miadında normal spontan vajinal yol ile 3200 gram doğan erkek bebek, postnatal ikinci gününde kusma, beslenememe şikayeti ile başvurusu sonrası neonatal sepsis ön tanısı ile yenidoğan servisinde yatırılarak 14 günlük tedavi ile taburculuktan 10 gün sonra sağ el bileği üzerinde şişlik şikayeti ile başvurdu. Şişlik dışında şikayeti olmayan olgunun fizik muayenesinde aktif, canlı görünümde, sağ el bileğinde üzerini örten deri sağlam görünümde olup, 3×3 $\mathrm{cm}$ boyutunda hareketli kitle palpasyonu dışında patoloji saptanmadı. El bileğinin çekilen direk grafisinde cilt altında kemik dokusuna benzer kalsifikasyon görüldü (Resim 2). Laboratuvar parametrelerinde; hemogram ve biyokimya değerleri normal aralıklarda, enfeksiyon markırları negatif saptandı. Hastanın yatış epikrizinde beslenemediği günlerde kitle lokalizasyonuna uyan bölgede periferik yerleşimli intravenöz kateterle kalsiyum glukonat içeren intravenöz

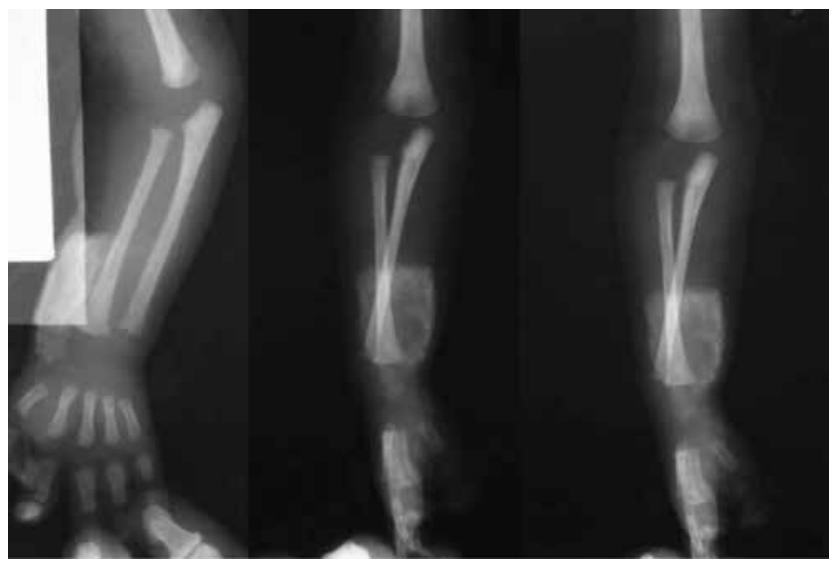

Resim 1. Olgu 1'deki deri kalsinozisi X-ray görüntüsü sıvı tedavisi aldığı öğrenildi. Intravenöz kalsiyum glukonat ekstravazasyonuna bağlı subkutan kalsinozis düşünülerek izleme alınan olguda 9 hafta sonra şişliğin gerilediği ve direk grafide kalsifikasyonun tamamen rezorbe olduğu görüldü.

\section{Tartışma}

Ekstravazasyon hasarları, sık görülmemesine rağmen ciddi komplikasyonlara yol açabilmektedir (4). Genellikle yüksek ozmolalitesi olan kimyasal maddeler ve katyonik solüsyonlar, kemoterapötikleri de içeren sitotoksik ya da iskemiyi indükleyebilen vazopressör ilaçlarla oluşmaktadır. Çoğu hasar erken tanı ile lokalize kalarak spontan olarak iyileşmektedir. Tedavide ekstremite elevasyonu, soğuk ya da sıcak uygulama ve uygun antidotun uygulanması yer almaktadır (2). Ancak daha çok el veya ayak dorsalinde görülen, geç tanı alan ciddi hasarlar fonksiyon kaybı, seri cerrahi operasyonlara rağmen amputasyonlarla sonuçlanabilmektedir.

Ekstravazasyon hasarları daha çok pediatrik ve geriatrik yaş grubunda görülmektedir (1). Yenidoğanlar immatür ve frajil derileri nedeni ile yüksek ekstravazasyon riskine sahiptirler (5). Yenidoğan yoğun bakım ünitelerinde, ekstravazasyon hasarlarına en sık intravenöz kalsiyum tedavisi sebep olmaktadır.

Deri kalsinozisi, kalsiyumun dermiste depolanmas olup distrofik, metastatik, iyatrojenik ve idiopatik olarak sınıflandırılmaktadır. Distrofik kalsinozis doku hasarı sonrası, metastatik kalsinozis kalsiyum ve fosfor metabolizma bozuklukları sonrası, iyatrojenik kalsinozis kalsiyum içeren solüsyonların ekstravazasyonu sonrası, idipatik kalsinozis ise patogenezi bilinmeyen mekanizmalarla oluşmaktadır (6-8). lyatrojenik kalsiyum ekstravazasyonuna bağlı olarak lokalize doku kalsifikasyonu, nekroz, selülit, osteomyelit ve Kompartman sendromu gelişebilmektedir (3). Sunulan iki olguda da ciltte belirgin lezyon olmadan cilt altında kalsiyum depolanması görüldü. Kalsiyum ekstravazasyonu tedavisinde elevasyon ve soğuk uygulama, lokal sodium sülfat ve selülöz fosfat enjeksiyonu, deri greftleme ve lokal triamsinolon asetonid enjeksiyonu yer almaktadır (7-9). Her iki olgu da tedavisiz izleme alındı ve tam iyileşme görüldü.

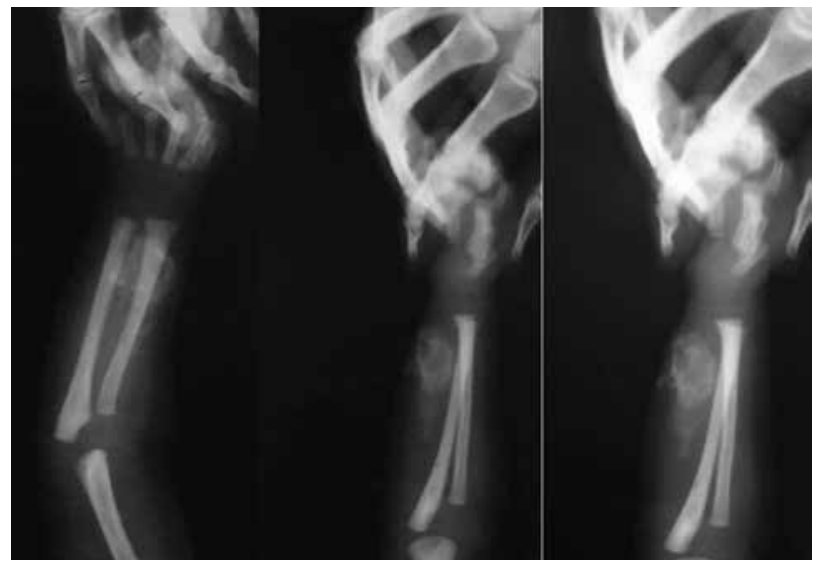

Resim 2. Olgu 2'deki deri kalsinozisi X-ray görüntüsü 
Kalsiyum içeren solüsyonların, hafif, subklinik ekstravazasyonu deri kalsinozisine yol açabileceği unutulmamalıdır. Her ne kadar komplikasyonun görünümü aileleri endişelendirse de uzun dönem ciddi bir sekel oluşturmamaktadır ve agresif tedaviye gerek duyulmadan spontan olarak iyileşebilmektedir.

\section{Kaynaklar}

1. Upton J, Mulliken JB, Murray JE. Major intravenous extravasation injuries. Am J Surg 1979; 137; 497-506.

2. MacCara ME. Extravasation: a hazard of intravenous therapy. Drug Intell Clin Pharm 1983; 17: 713-7.

3. Chen TK, Yang CY, Chen SJ. Calcinosis cutis complicated by compartment syndrome following extravasation of calcium gluconate in a neonate: a case report. Pediatr Neonatol 2010; 51: 238-41.
4. Celbek G, Gungor A, Albayrak H, Kir S, Guvenc SC, Aydin $Y$. Bullous skin reaction seen after extravasation of calcium gluconate. Clin Exp Dermatol 2013; 38 :154-5.

5. Barker N, Hadgr aft J, Rutter N. Skin permeability in the newborn. J Invest Dermatol 1987; 88: 409-11.

6. Goldminz D, Barnhill R, McGuire J, Stenn KS. Calcinosis cutis following extravasation of calcium chloride. Arch Dermatol 1988; 124: 922-925.

7. Hironaga M, Fujigaki T, Tanaka S. Cutaneous calcinosis in a neonate following extravasation of calcium gluconate. J Am Acad Dermatol 1982; 6: 392-5

8. Moss J, Syrengelas A, Antaya R, Lazova R. Calcinosis cutis: a complication of intravenous administration of calcium glucanate. J Cutan Pathol 2006; 33: 60-2.

9. Ahn SK, Kim KT, Lee SH, Hwang SM, Choi EH, Choi S. The efficacy of treatment with triamcinolone acetonide in calcinosis cutis following extravasation of calcium gluconate: a preliminary study. Pediatr Dermatol 1997; 14: 103-9. 